determined. The components of managerial competence, as well as practical methods and ways that enhance their formation have been described: ethical (method of lecture, emotional stimulation, problem situation, conversation,); communicative (lectures, learning discussions, practices through action, games); health-preserving competence (lectures, problem-searching, analytical); self-development and selfeducation (lectures, independent work, explanation, research, partially-search); productive activity (problem lecture, analytical, diagnostics); conflict (lectures, training, discussion, simulation); psychological (lectures, explanatory-motivating, constructive (simulation)); general-industry (lectures, analyticalresearch, modelling); economic (lectures, visual-demonstration, interactions); legal (lectures, problem, explanatory-demonstration); subject-methodical (lectures, independent research, informational-visual); diagnostic (lectures, analytical, expert,); educational (lectures, visual, project, research); informational (lectures, practical, partially-search); technical (lectures, instructing, practical).

A skillful combination of practical teaching methods and techniques in the formation of the managerial competence of future heads of institutions of general secondary education will affect the quality of the organization of the educational process, the level of mastery of the content of competencies, the level of motivation of graduate students, the level of mastery of practical skills and abilities, and the ability to realize managerial competence.

Keywords: future manager, training, competence approach, managerial competence, components of managerial competence, practical methods and ways.

DOI: https://doi.org/10.31392/NZ-npu-142.2019.09

УДК 371.134:373

Долбишева Н. Г., Михайліченко А. Г.

\title{
МЕТОДИКА ВДОСКОНАЛЕННЯ ТЕХНІЧНОЇ ПІДГОТОВКИ ЧЕРЛІДИРІВ НА ЕТАПІ ПОПЕРЕДНЬОЇ БАЗОВОЇ ПІДГОТОВКИ
}

У статті представлена експериментальна методика вдосконалення технічної підготовки черлідирів, яка була впроваджена в навчально-тренувальний процес дітей 9-12 років на етапі попередньої базової підготовки. Дана методика побудована на основі теоретичних положеннь: теорії та методики спортивного тренування, системи підготовки спортсменів в техніко-естетичних видах спорту, основних закономірностей процесу навчання та вдосконалення техніки фізичних вправ у складнокоординаційних видах спорту, особливостей підготовки та змагальної діяльності у черлідингу, особливостей виконання черлідирами різних функиій в процесі змагальної композиції. А також попередніх досліджень щчодо місия та значення технічної підготовки в навчально-тренувальному прочесі юних спортсменів-черлідирів на етапі попередньої базової підготовки та вихідного рівня технічної та фізичної підготовленості спортсменок-черлідирів.

Експериментальна методика охоплює три рівня технічної підготовки, для яких було окремо визначено мету та завдання підготовки, власні засоби та методи спортивного тренування та які планувалися відповідно до структури двохщиклової річної підготовки з урахуванням поставлених завдань мезочиклу.

Спортивна підготовка з черлідингу побудована як иілорічний прочес і має певні часові проміжки для вирімення основних завдань навчально-тренувального процесу. Пріоритетною стороною черлідирів є технічна підготовка, оскільки основним критерієм оцінки виступу команди на змаганнях є якість та складність виконання технічних елементів.

Обтрунтовано методику вдосконалення технічної підготовки черлідирів 9-12 років на етапі попередньої базової підготовки. Встановлено, щуо річний цикл підготовки юних черлідирів 
на етапі попередньої базової підготовки має двохииклову макроструктуру.

Виховуючи навички максимального прояву сил та реалізаиії рухового потениіалу під час виконання загальної композиції, досягнення стабільності і варіативності змагальної композииї, щуо складає основу загальної діяльності, спортсмени-черлідири виходять на новий рівень підготовленості.

Ключові слова: черлідинг, черлідири-база, черлідири-флаєри, технічна підготовка, технічна підготовленість, етап попередньої базової підготовки, вдосконалення, методика.

Відмінною особливістю будь-якого спорту, зокрема і черлідингу, $\epsilon$ змагальна діяльність, яка вкладається в рамки змагань. Тому вся підготовка спортсменів-черлідирів спрямована до виступів в основних змаганнях сезону, притому 3 орієнтацією на перемогу, встановлення рекорду і найгострішу конкуренцію. Прагнення до вищих досягнень не припиняється, а темпи їх зростання практично не слабшають. Це відбувається завдяки використанню найбільш ефрективних засобів і методів тренування, інтенсифікації тренувального процес та змагальної діяльності $[1,11,16]$.

Черлідинг належить до складно-координаційних видів спорту, рухова діяльність яких характерна надзвичайно високими вимогами до техніки рухів і різних якостей $[1,10]$. Складно-естетичні види спорту висувають підвищені вимоги до опорно-рухового апарату, до амплітуди рухів у суглобах, до механічної міцності кісток і суглобів, до амортизуючої функції стопи і вигинів хребта. Спортсменам з черлідингу при виконанні змагальних програм доводиться застосовувати значну кількість рухових дій: махи, присідання, стрибки, падіння, обертання тощо [3, 9, 18].

Наукові дослідження і практичний досвід свідчать про те, що при сучасному рівні розвитку черлідингу та спорту взагалі одній людині практично неможливо досягти однаково високих досягнень не тільки в різних видах спорту, а й у різних номінаціях черлідингу: "Cheer", “Dans", “J az" та “Urban”. Тому черлідинг вимагає граничної концентрації сил і часу під час тренування, прямо або опосередковано процесу підготовки до виступу в конкретних номерах змагальної програми [21].

Спортивна підготовка з черлідингу побудована як цілорічний процес і має певні часові проміжки для вирішення основних завдань навчальнотренувального процесу. Пріоритетною стороною черлідирів $\epsilon$ технічна підготовка, оскільки основним критерієм оцінки виступу команди на змаганнях $\epsilon$ якість та складність виконання технічних елементів [4].

Під технічною підготовленістю спортсмена розуміють ступінь освоєння спортсменом системи рухів, відповідних особливостям даного виду спорту і спрямованої на досягнення високих спортивних результатів [12].

Вік 9-12 років відповідає етапу попередньої базової підготовки 3 черлідингу, однак дотепер відсутні дослідження, що розкривають особливості технічної підготовки спортсменів, зміст та структуру побудови тренувального процесу на цьому етапі.

На цей час проведені наукові дослідження, присвячені питанням підготовки черлідирів різного віку $[2,7,12,20]$, а саме їх техніко-тактичної підготовки [6, 9, 13], проблемам психологічної підготовки [3, 20].

Такий стан питання робить актуальним обґрунтування методики підвищення рівня технічної підготовленості юних черлідирів на етапі початкової-базової підготовки. 
Дослідження виконане згідно із Зведеним планом НДР у сфері фрізичної культури і спорту на 2016-2020 рр. за темою: “сторичні, організаційно-правові та теоретико-методичні основи підготовки спортсменів в неолімпійському спорті" державний реєстраційний номер $0116 \mathrm{U} 003008$.

Мета дослідження - обґрунтувати методику вдосконалення технічної підготовки черлідирів 9-12 років на етапі попередньої базової підготовки.

Методи дослідження: аналіз науково-методичної літератури та документальних матеріалів.

В основу експериментальної методики вдосконалення технічної підготовки черлідирів на етапі попередньої базової підготовки першого року тренувань було покладено теоретичні положення: теорії та методики спортивного тренування В.Н. Платонова [15, 17], Ю.Ф.Курамшин, [11] та ін.; системи підготовки спортсменів в техніко-естетичних видах спорту Ю. К. Гавердовського [4]; основних закономірностей процесу навчання та вдосконалення техніки фрізичних вправ у складнокординаційних видах спорту О. М. Худолія [19], Ю. К. Гавердовського [4] та ін.; особливостей підготовки та змагальної діяльності у черлідингу В. С. Афртайкін [1], А. А. Боляк [3], А. Н. Бекетова [2], Н. Г.Долбишева, В. В. Кидонь [5], І. А. Зинченко, Л. С. Луценко, І. А. Бодренкова [7], Р.Чеппел [19] та ін. Також при розробці експериментальної методики ураховувалися результати попередніх досліджень щодо місця та значення технічної підготовки в навчальнотренувальному процесі юних спортсменів-черлідирів на етапі попередньої базової підготовки [13], вихідного рівня технічної та фрізичної підготовленості спортсменок-черлідирів, які виконують в процесі змагальної композиції різні функції ("базу" (перший рівень пірамід) та "флаєри" (другий та третій рівень пірамід) [6, 14].

Встановлено, що річний цикл підготовки юних черлідирів на етапі попередньої базової підготовки має двохциклову макроструктуру, яка складається з двох підготовчих, 2 змагальний та 1 перехідного періодів, які охоплюють мезоцикли. Кожен період та мезоцикл вирішує свої завдання (табл. 1).

Табличя 1

Структура та завдання мезоциклів в річному циклі підготовки спортсменок-черлідирів на етапі попередньої базової підготовки периого року тренувань

\begin{tabular}{|c|c|}
\hline \multicolumn{2}{|l|}{ I - підготовчий період (вересень-жовтень) } \\
\hline \multicolumn{2}{|l|}{ мезоцикли } \\
\hline втягуючий (вересень) & базовий (жовтень) \\
\hline $\begin{array}{l}\text { Завдання: Повторення обсягу рухових } \\
\text { умінь і навичок, основ спортивної техніки з } \\
\text { черлідингу, які були отримані на } \\
\text { попередньому етапі спортивної підготовки, } \\
\text { що сприятиме активній участі спортсмена у } \\
\text { здійсненні технічної підготовки. }\end{array}$ & $\begin{array}{l}\text { Завдання: Досягнення стабільності і } \\
\text { варіативності елементів, що складають } \\
\text { основу техніки виду спорту. Повторення та } \\
\text { вдосконалення елементів першого рівня } \\
\text { технічної підготовки. Формування навичок } \\
\text { виконання вправ другого рівня технічної } \\
\text { підготовки. }\end{array}$ \\
\hline I - змагальний мезоцикл (листопад-грудень) & \\
\hline
\end{tabular}




\begin{tabular}{|c|c|c|c|}
\hline базовий (листопад) & & Змагальний (гр & удень) \\
\hline $\begin{array}{l}\text { Завдання: вдосконалення та } \\
\text { вивчених елементів першог } \\
\text { рівня технічної підготовки } \\
\text { програму змагальної кол } \\
\text { підвищення } \\
\text { майстерності. }\end{array}$ & $\begin{array}{l}\text { впровадження } \\
\text { о та другого } \\
\text { впровадити в } \\
\text { ипозиції для } \\
\text { професійної }\end{array}$ & $\begin{array}{l}\text { Завдання: } \Phi \\
\text { максимального } \\
\text { рухового поте } \\
\text { загальної комп }\end{array}$ & $\begin{array}{l}\text { ормування навиків щодо } \\
\text { прояву сил та реалізації } \\
\text { енціалу під час виконання } \\
\text { озиції. }\end{array}$ \\
\hline II - підготовчий період (січен & Б-березень) & & \\
\hline мезоцикли & & & \\
\hline Відновлювальний (січень) & базовий (люти) & & $\begin{array}{l}\text { контрольно-підготовчий } \\
\text { (березень) }\end{array}$ \\
\hline $\begin{array}{l}\text { Завдання: Вдосконалення } \\
\text { навиків першого та другого } \\
\text { рівня технічної підготовки. }\end{array}$ & $\begin{array}{l}\text { Завдання: В } \\
\text { та ускладнені } \\
\text { рухових дій } \\
\text { технічної пі, } \\
\text { динаміки і } \\
\text { урахуванням ің } \\
\text { особливостей г }\end{array}$ & $\begin{array}{l}3 \text { досконалення } \\
\text { ня структури } \\
\text { другого рівня } \\
\text { дготовки, їх } \\
\text { кінематики } 3 \\
\text { ндивідуальних } \\
\text { черлідирів }\end{array}$ & $\begin{array}{lr}\text { Завдання: } & \text { Вдосконалення } \\
\text { всіх елементів другого рівня } \\
\text { технічної } & \text { підготовки. } \\
\text { Досягнення } & \text { стабільності i } \\
\text { варіативності } & \text { змагальної } \\
\text { композиції, } & \text { що складає } \\
\text { основу } & \text { змагальної } \\
\text { діяльності } & \end{array}$ \\
\hline II - змагальний мезоцикл (кві & гень-травень) & & \\
\hline мезоцикли & & & \\
\hline передзмагальний (квітень) & & змагальний (тр & авень) \\
\hline $\begin{array}{l}\text { Завдання: Вдосконалення ф } \\
\text { та психічних можливості } \\
\text { виведення їх на но } \\
\text { підготовленості; Впровад } \\
\text { елементів першого та } \\
\text { технічної підготовки дс дс } \\
\text { композиції. }\end{array}$ & $\begin{array}{rr}\text { ункціональних } \\
\text { ¿портсменок і } \\
\text { вий } & \text { рівень } \\
\text { ження } & \text { всіх } \\
\text { ругого } & \text { рівня } \\
\text { змагальної }\end{array}$ & $\begin{array}{l}\text { Завдання: } \\
\text { першого та } \\
\text { підготовки на } \\
\text { композиції } \\
\text { професійної ма }\end{array}$ & 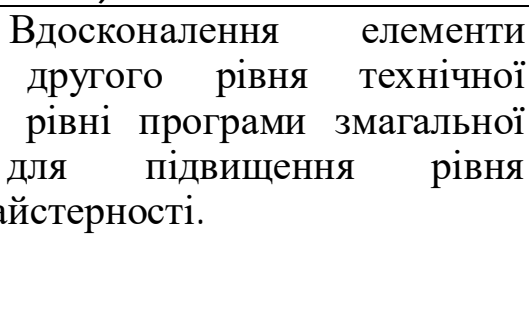 \\
\hline II - перехідний період (червег & (ь-серпень) & & \\
\hline мезоцикл & & & \\
\hline відновлювальний (червень-с & ень) & & \\
\hline $\begin{array}{l}\text { Завдання: Сприяти активно } \\
\text { спеціальної фізичної підготов } \\
\text { та другого рівня технічної }\end{array}$ & $\begin{array}{l}\text { му відпочинку, } \\
\text { теності. Закріпл }\end{array}$ & $\begin{array}{l}\text { підтримці дос } \\
\text { ення елементів }\end{array}$ & $\begin{array}{l}\text { ягнутого рівня загальної та } \\
\text { та їх вдосконалення першого } \\
\text { рівні вмінь елементів, що } \\
\text { зки другого року тренувань }\end{array}$ \\
\hline
\end{tabular}

Враховуючи вищезазначене, наша методика складається з трьох рівнів підготовки спортсменів-черлідирів, для яких було окремо визначено мету та завдання підготовки, власні засоби та методи спортивного тренування (рис. 1) і планувалися відповідно до структури мезоциклів:

І рівень методики - у втягуючому мезоциклі першого підготовчого періоду та відновлювальному мезоциклі другого підготовчого періоду;

II рівень методики - у базовому мезоциклі першого та другого підготовчих періодів та контрольно-підготовчому мезоциклі другого підготовчого періоду;

III рівень методики - у базовому та змагальному мезоциклах першого змагального періоду та передзмагальному та змагальному мезоциклах другого змагального періоду.

На першому рівні технічної підготовки спортсменів-черлідирів наша методика складала з фронтальної підготовки фрлаєрів та бази. Основними компонентами технічної підготовки було визначено: положення рук, Чер- 
стрибки, акробатичні елементи на онові яких й складається наша методика.

Метою першого рівня підготовки $€$ повторення і вдосконалення навичок технічної підготовки, сфрормованих на етапі початкової підготовки з черлідингу.
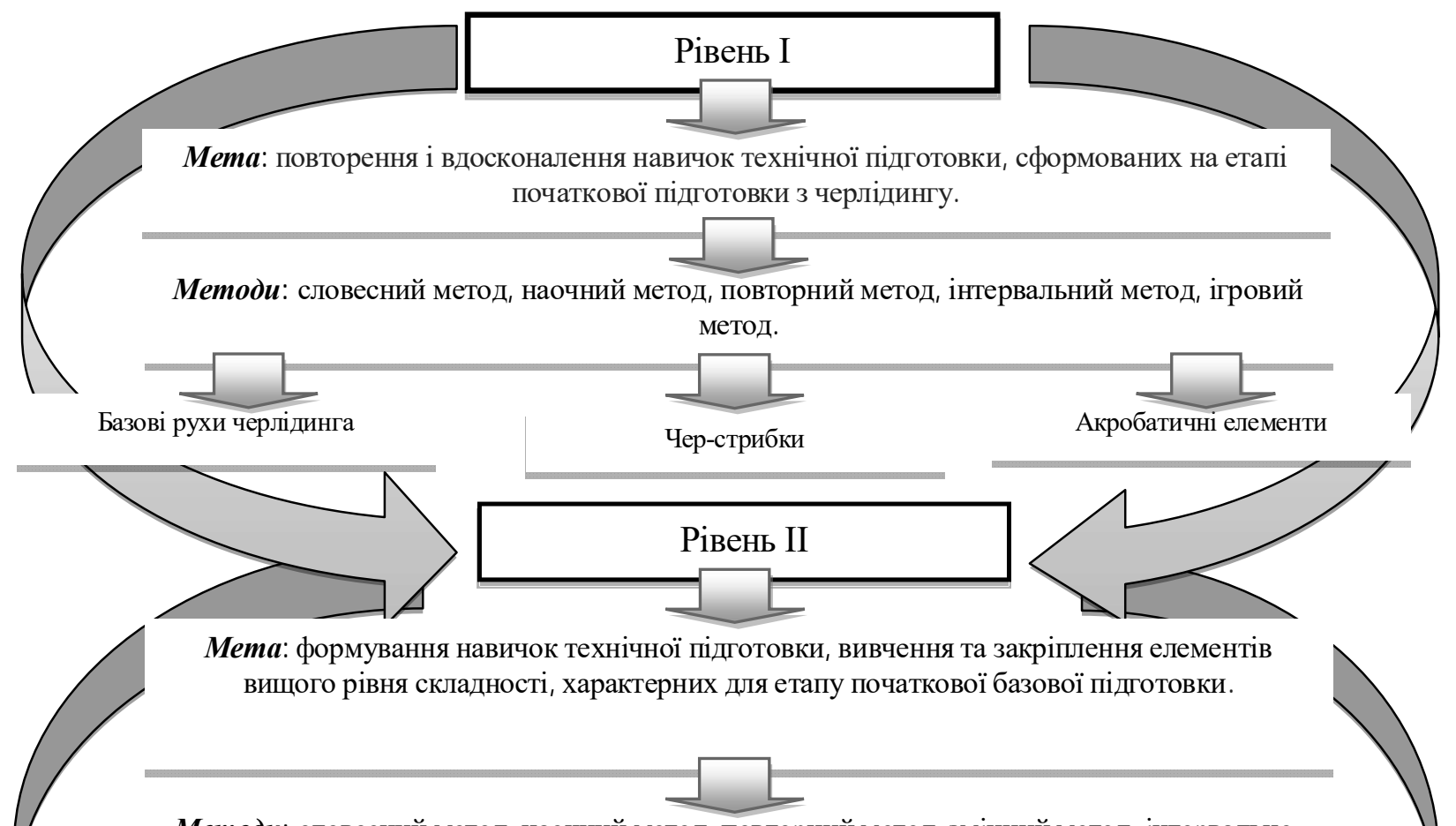

Memoдu: словесний метод, наочний метод, повторний метод, змінний метод, інтервальноперемінний, метод суворої регламентації, метод колового тренування, метод безперервного виконання вправ.

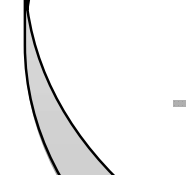

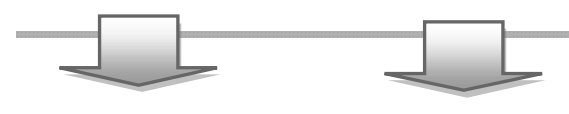

Базові рухи челідинга
Чер-стрибки

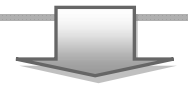

Акробатичні елементи
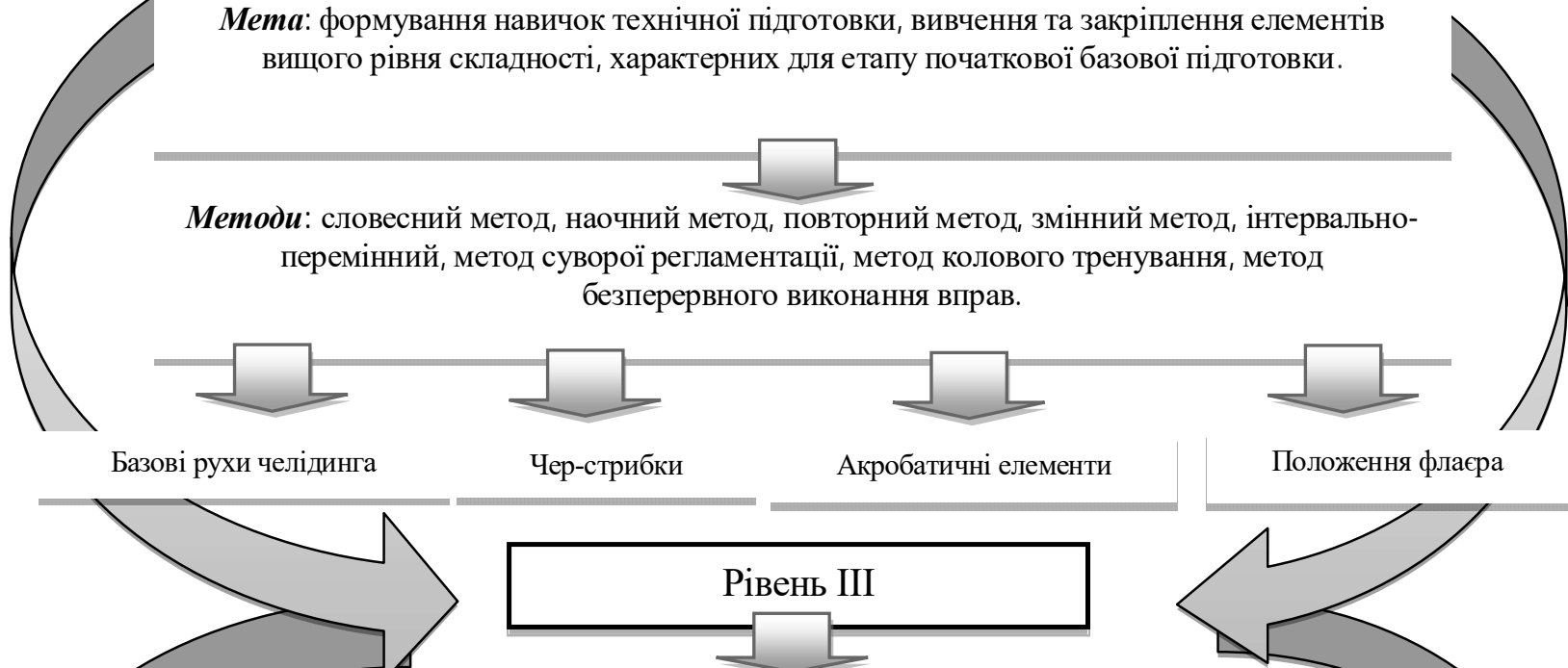

Mema: формування навичок виконання змагальних вправ у структурі змагальної композиції з черлідингу під час виступу на змаганнях у номінації «Cheer», формування навичок технічної підготовки, вивчення та закріплення елементів вищого рівня складності, характерних для етапу початкової базової підготовки.

Методи: змагальний метод.
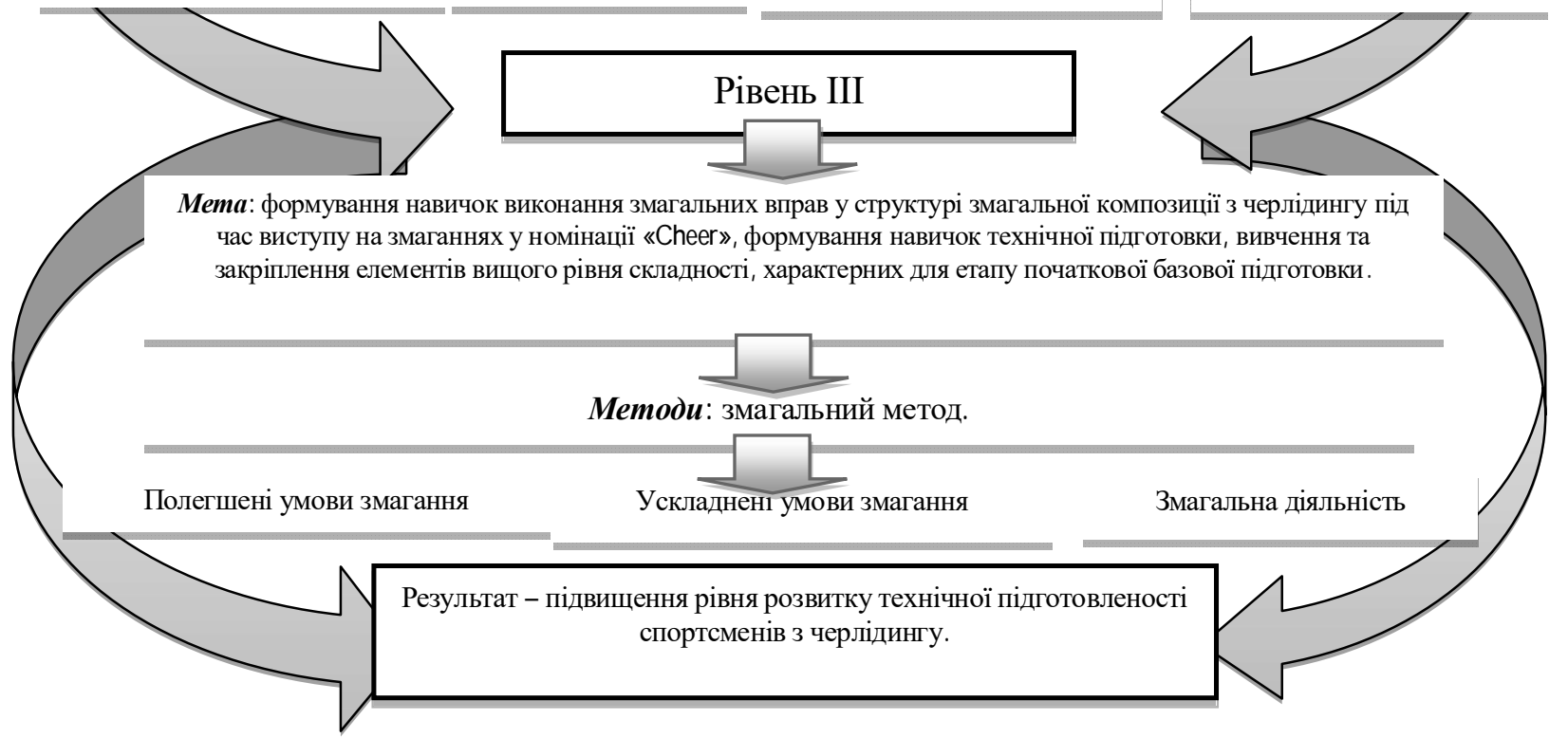

Рис.1. Основі складові (рівні) експериментальної методики технічної підготовки спортсменів-черлідирів 
Для вдосконалення техніки виконання базових рухів був розроблений блок фізичних вправ з елементами основних положень рук (Блок вправ ПР), блоки фізичних вправ на вдосконалення стрибків (Блок вправ ЧС) та блоки вправ на вдосконалення акробатичних елементів (Блок вправ АЕ) (табл. 2).

Таблиця 2

\section{Блоки фізичних вправ технічної підготовки I рівня}

\begin{tabular}{|c|c|c|c|c|c|}
\hline \multicolumn{6}{|c|}{ Блок вправ ПР } \\
\hline \multicolumn{6}{|c|}{\begin{tabular}{l|l}
1. & "Hands on hips"
\end{tabular}} \\
\hline 2. & Higt “V” & 8. & "Frame" & 14. & Touch \\
\hline 3. & Low "V" & 9. & "Right diagonal" & 15. & $\begin{array}{ll}\text { Right } & \text { Bowand } \\
\text { A rrow } & \end{array}$ \\
\hline 4. & "T" & 10. & "L eft diagonal" & 16. & Left “L” \\
\hline 5. & Broken "T" & 11. & Right "K" & 17. & Right "K" \\
\hline 6. & "L eft Punch Up" & 12. & Left "K" & 18. & "Injun" \\
\hline \multicolumn{3}{|c|}{ Блок вправ ЧС } & \multicolumn{3}{|l|}{ Блок вправ AE } \\
\hline 1. & "Стредл" & 1. & \multicolumn{3}{|l|}{ Перекид вперед } \\
\hline 2. & "Угрупування" & 2. & \multicolumn{3}{|l|}{ Перекид назад } \\
\hline 3. & "Херки" & 3. & \multicolumn{3}{|c|}{ Стійка на руках } \\
\hline \multirow{2}{*}{4.} & \multirow{2}{*}{ Блок зв’язок } & 4. & \multicolumn{3}{|c|}{ Переворот в сторону ("Колесо") } \\
\hline & & 5. & "Mict" & & \\
\hline
\end{tabular}

Повторення та вдосконалення базових рухів черлідингу було здійснене за допомогою виконання кожного положення окремо та з урахуванням методичних підходів. Так, виконання вправ з демонстрацією тренера, виконання вправ біля дзеркала без демонстрації тренера, виконання базових рухів кожним учасником команди, виконання базових рухів черлідингу синхронно всією командою.

Слід зазначити, що кисть повинна бути продовженням руки і "не заламуватись" під час виконання та зміни рухів. $€ 4$ базових положення кистей: кулак (чотири пальці стиснуті в кулак, а великий палець притиснутий поверх них, кулак та зап'ястя знаходяться на одній лінії), клинок (пальці витягнуті, великий палець притиснутий, долоню плоска), клеп (долоні з'єднуються плиском), клапс (одна долоня захоплює іншу). Базові рухи можуть бути виконані з будь-яким з двох положень кисті: кулак або клинок, положення кистей для всієї команди визначає тренер.

Чер-стрибок - швидке, різке переміщення тіла вгору відштовхуванням ніг від точки опори з виконанням виду стрибка в повітрі і подальшим приземленням на дві ноги. Чер-стрибки (Блоки вправ ЧС) спортсменами черлідирами повторювались та вдосконалювались за допомогою блоків вправ Блок вправ ЧС-1 “Стредл”, Блок вправ ЧС-2 “Угрупування”, Блок вправ ЧС-3 "Херки" за рахунок виконання стрибків перед дзеркала, з платформи 30 см, самостійного виконання та синхронного виконання командою загалом. Важливим $є$ техніка, висота і чистота стрибка, включаючи приземлення.

Також велика увага приділяється повторенню та вдосконаленню акробатичних елементів (Блоки вправ $A E)$, які в свою чергу були розділені на 
блоки вправ Блок вправ AE-1 “Перекид вперед”, Блок вправ AE-2 “Перекид назад", Блок вправ AE-3 Стійка на руках, Блок вправ AE-4 "Переворот боком (“Колесо")", та Блок вправ AE-5 “Міст”.

На другому рівні методика окремо складалась з підготовки черлідирівфллаєрів та черлідирів-бази, що надало можливість більш індивідуально підійти до питання щодо підвищення рівня технічної підготовки кожного з членів команди.

Метою другого рівня $€$ формування навичок технічної підготовки, вивчення та закріплення елементів вищого рівня складності, характерних для етапу початкової базової підготовки.

На другому рівні підготовки спортсменів-черлідирів блоки вправ були направлені на вдосконалення та вивчення елементів технічної підготовки. Для цього нами були розроблені три блоки вправ зі зв'язками базових положень рук, шість блоків вправ Чер-стрибків, десять блоків акробатичних елементів та п'ять блоків положень фрлаєра.

Для розвитку рухової пам'яті було запропоновано вивчення зв'язки 3 5 базових положень рук черлідинга, які були складені у Блоки прав ПР-1, ПР-2, ПР- (табл. 3). Під час виконання зв'язок кисті повинні бути зібрані у кулаки, великий палець зверху, руки мають бути сильними та напруженими, а рухи руками - різкими та чіткими. Положення корпусу: шия витягнута, плечі опущені, очі підняті вверх, поперек без прогину, прес-сідниці-ноги максимально напружені, коліна рівні.

Таблиця 3

\section{Блоки фізичних вправ “Положення рук" другого рівня технічної підготовки}

\begin{tabular}{|c|c|}
\hline \multicolumn{2}{|c|}{ Блок вправ ПР-1 } \\
\hline 1. & "Hands on hips"+ Higt "V"+ Broken "T" + Low "V"+"Low Touch down" \\
\hline 2. & “Left Punch Up"+"Injun"+“D aggers”+"Right Punch Up"+ Low “V” \\
\hline 3. & Right B owand A rrow + L eft "L" + Right "L" + Left Bowand A rrow +"Frame" \\
\hline \multicolumn{2}{|c|}{ Блок вправ ПР-2 } \\
\hline 1. & "Touch down" +L eft B owand A rrow+"T" + Right Bowand A rrow +"Touch down" \\
\hline 2. & "Injun"+Right "K"+ "Hands on hips"+ Left "K"+"Low Touch down" \\
\hline 3. & "Frame" +"Right diagonal" + B roken "T"+ "L eft diagonal"+"Touch down" \\
\hline \multicolumn{2}{|c|}{ Блок вправ ПР-3 } \\
\hline 1. & "Right diagonal" +Right "K"+ Left "K"+"L eft diagonal" +“Daggers" \\
\hline 2. & Broken "T" + "Touch down"+ Broken "T"+"T" ${ }^{\prime \prime "+" L o w ~ T o u c h ~ d o w n " ~}$ \\
\hline 3. & \\
\hline
\end{tabular}

Оскільки на змаганнях враховується техніка, висота та чистота стрибка, включаючи приземлення на другому рівні, наша методика включає в себе блоки вправи направлення на вдосконалення Чер-стрибків (ЧС-1 “Стредл", ЧС2 “Угрупування", ЧС-3 “Херки”) та вивчення нових (ЧС-4 "Пайп”, ЧС-5 “Той-Тач”, чС-6 "Навколо світу") (рис. 2). 


\begin{tabular}{|c|c|c|c|}
\hline & \multicolumn{2}{|c|}{ Блок вправ ЧС “Чер-стрибки” } & \\
\hline \multicolumn{2}{|c|}{ Вдосконалення } & \multicolumn{2}{|c|}{ Вивчення } \\
\hline Блок вправ ЧС-1 & “Стредл” & Блок вправ ЧС-4 & “Пайп” \\
\hline Блок вправ ЧС-2 & “Угрупування" & Блок вправ ЧС-5 & “Той-Тач" \\
\hline Блок вправ ЧС-3 & “Херхи" & Блок вправ ЧС-6 & "Навколо світу" \\
\hline
\end{tabular}

Рис. 2. Блоки вправ "Чер-стрибки" другого рівня технічної підготовки

Вдосконалення Чер-стрибків здійснювалось за рахунок виконання Черстрибка та зв'язки Чер-стрибків командою та вправ направлених на розвиток фрізичних якостей. А вивчення за рахунок виконання імітації Чер-стрибка з в.п. лежачи на спині, виконання Чер-стрибка біля дзеркала, самостійного виконання Чер-стрибка та виконання Чер-стрибка командою.

Також на другому етапі технічної підготовки велика увага була приділена акробатичним елементам, їх вдосконаленню та вивченню нових, більш складних вправ. На вдосконалення були направлені блоки вправ AE-1 “перекид вперед", AE-2 “перекид назад”, AE-3 “стійка на руках", AE4 "переворот в сторону (“Колесо")", АE-5 “Міст", а на вивчення - AE-6 “Рандат", AE-7 "переворот вперед через "Міст'", АE-8 “переворот вперед на одну ногу", AE-9 "Переворот назад на одну ногу", AE-10 "переворот вперед із стійки на руках (темповий переворот)" (рис. 3).

\begin{tabular}{|c|c|c|c|}
\hline & \multicolumn{3}{|c|}{ Блок вправ AE «Акробатичні елементи» } \\
\hline & Вдосконалення & & Вивчення \\
\hline Блок вправ AE-1 & Перекид вперед & Блок вправ AE-6 & Рандат \\
\hline Блок вправ AE-2 & Перекид назад & Блок вправ AE-7 & Переворот вперед через «Міст» \\
\hline Блок вправ AE-3 & Стійка на руках & Блок вправ АЕ-8 & Переворот вперед на одну ногу \\
\hline \multirow[t]{2}{*}{ Блок вправ AE-4 } & \multirow{2}{*}{$\begin{array}{l}\text { Переворот боком } \\
\text { («Колесо») }\end{array}$} & Блок вправ AE-9 & Переворот назад на одну ногу \\
\hline & & \multirow{2}{*}{$\begin{array}{r}\text { Блок вправ } \\
\mathrm{AE}-10\end{array}$} & \multirow{2}{*}{$\begin{array}{l}\text { Переворот вперед із стійки на } \\
\text { руках (темповий переворот) }\end{array}$} \\
\hline Блок вправ AE-5 & Гімнастичний «міст» & & \\
\hline
\end{tabular}




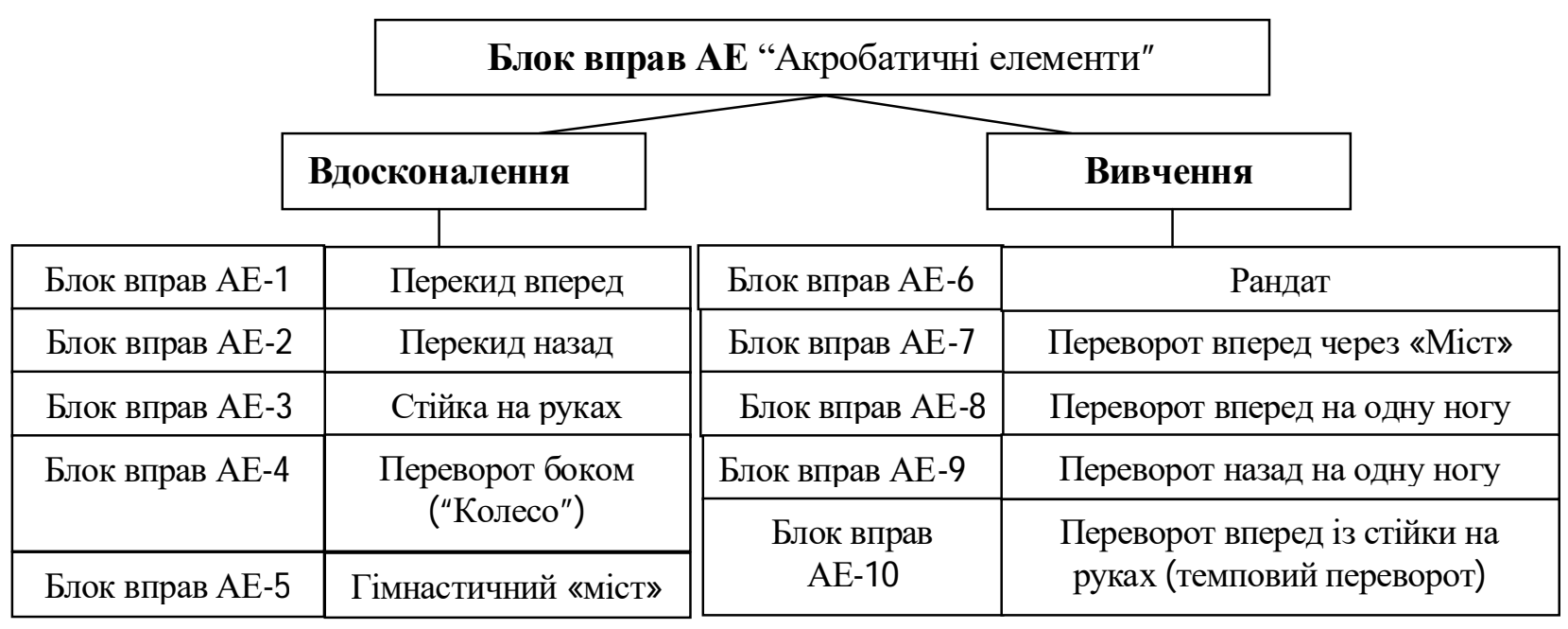

Рис. 3. Блоки вправ АЕ" Акробатичних елементів" другого рівня технічної підготовки

А. С. Носкова вважає, що акробатичні вправи різнобічно впливають на організм спортсменів-черлідирів: сприяють розвитку сили, швидкості, точності рухів, розвивають здатність орієнтуватися в просторі, мають великий вплив на тренування вестибулярного апарату, удосконалюють ффункцію рівноваги [15]. Л. С. Луценко та І. О. Зінченко також вважають, що акробатична підготовка у навчально-тренувальному процесі відіграє вирішальну роль у вдосконалені спортивного майстерства черлідирів [9]. Тому для вдосконалення рівня технічної підготовленості нами були використані наступні варіанти виконання вправ: виконання 3 допомогою тренера, виконання вправи самостійно, 3 утриманням однієї ноги під кутом 90, виконання з місця або з розбігу.

Для черліирів-фрлаєрів розроблена нами методика включала вправи для підвищення рівня складності положень флаєра. Блоки вправ включали в себе, як вправи на вдосконалення (Блок вправ ПФ-1 “Основна стійка" Блок вправ ПФ2 "Ліберті") так і на вивчення нових положень (Блок вправ ПФ-3 “Стег”, Блок вправ ПФ-4 “Прапорець”, Блок вправ ПФ-5 “Скорпіон”) (рис. 4).

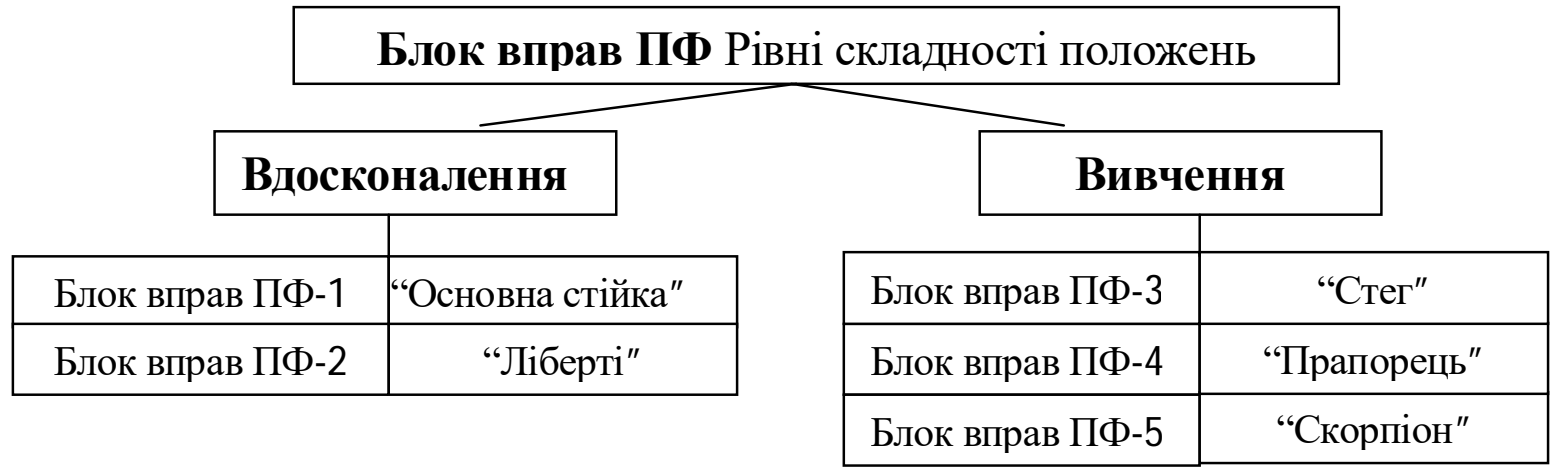

Рис. 4. Блок вправ ПФ "Положення флаєрів" другого рівня технічної підготовки

Оскільки черлідир-фрлаєр - це спортсмен, який не має контакту 3 поверхнею майданчика під час виконання стантів та пірамід, підвищення рівня складності положень фрлаєра відбувалось шляхом вдосконалення та вивчення 
нових положень. Так, черлідири-фрлаєри виконували положення спочатку на підставці розміром - висота 40 см, довжина 50 см, ширина 30 см; потім виконання положення відбувалося безпосередньо у станті, а в подальшому 3 обтяженням у 1 кг (2*0,3 кг для ніг та 2*0,2 кг для рук), що сприяло додатково розвитку фрізичних якостей (силових здібностей верхнього плечового поясу). Для вивчення нових елементів також були включені вправи на акробатичній доріжці та виконання стантів з допомогою тренера.

Змагальна діяльність - це незамінна школа вдосконалення здібностей спортсменів, їх умінь та навичок у структурі змагальної композиції. Тому mpemiŭ рівень методики складався безпосередньо з підготовки та виступу команди на змаганнях, які входили до річного плану загань.

Метою третього рівня $€$ підвищення рівня змагальної композиції 3 черлідингу на етапі попередньої базової підготовки

Третій рівень спортивної підготовки з черлідингу був виконаний за рахунок змагального методу, оскільки найбільш характерними ознаками змагального методу є:

- $\quad$ зіставлення сил спортсменок з метою виявлення переможця. Перемозі була підпорядкована вся діяльність відповідно до встановлених правил;

- змагальний метод давав можливість повністю розкрити функціональні та психічні можливості спортсменок і вивести їх на новий рівень підготовленості;

- стимулювання творчої активності самостійності, ініціативи тощо;

- обмежені можливості регулювати навантаження спортсменів.

Змагальна діяльність сприяла вихованню і фрормуванню навичок максимального прояву сил та реалізації рухового потенціалу в повній мірі. Лише у процесі змагань спортсмен може вийти на рівень граничних функціональних проявів і виконувати таку роботу, яка під час тренувальних занять виявляється непідсильною. Дослідження (В. М. Платонов) показують, що у звичайних умовах тренування коливання сили при повторних вимірюваннях, як правило, не перевищують 3-4\%. Якщо ж повторні вимірювання виконуються в умовах змагань, або при відповідній мотивації, то приріст сили може становити 10-15\%, а в окремих випадках - 20\% і більше.

Для забезпечення таких ефектів змагання можуть проводитись в ускладнених або полегшених умовах порівняно з тими, що характерні для ооріційних змагань.

Ускладнення: виконання змагальної композиції на менших або більших майданчиках, повторення композиції декілька разів з невеликими паузами, застосування обтяжень та ін.

Полегшення: виконання композиції по частинах, виконання композиції без музичного супроводу, скорочення програми загалом, спрощення програми.

Таким чином, виховуючи навички максимального прояву сил та реалізації рухового потенціалу під час виконання загальної композиції, досягнення стабільності і варіативності змагальної композиції, що складає основу загальної діяльності спортсмени-черлідири виходять на новий рівень підготовленості.

Висновок:

1. Технічна підготовка $€$ основною складовою в загальній системі 
підготовки спортсменів-чирлідирів на етапі попередньої базової підготовки, яка у номінації "Cheer" складається з окремих компонентів, таких як: Чер-стрибки, елементи акробатики, станти, піраміди, Чер-Данс хореографрія, Чир та Чант кричали. Також, технічна підготовка в навчально-тренувальному процесі займає вагоме місце та в середньому складає $31 \%$ від загального часу тренувань.

2. Технічна та фрізична підготовка черлідирів займає провідне місце в навчально-тренувальному процесі, оскільки результат змагальної діяльності визначається на основі технічної майстерності виконання змагальної композиції, а рівень фізичної підготовленості впливає на якісні характеристики техніки виконання композиційних вправ.

3. Експериментальна методика складається 3 трьох рівнів технічної підготовки спортсменів - черлідирів, для яких було окремо визначено мету та завдання підготовки, власні засоби та методи спортивного тренування та планувалися відповідно до структури мезоциклів. Кожен рівень технічної підготовки планується з урахування поставлених завдань певного мезоциклу двохциклового річного циклу.

Перспективами подальшого дослідження $€$ аналіз результатів технічної та фрізичної підготовленості спортсменів-черлідирів після впровадження розробленої нами методики.

\section{Використана література:}

1. Афтайкін В. С. Применение усложнённых упражнений для развития координационных способностей юных черлидиров на начальном этапе обучения. Ученые записи университета имени П. Ф. Лесгафта. 2015. № 5. С. 24.

2. Бекетова А. Н. "Черлидинг”: Методические указания. Харьков, 2017. 19 с.

3. Боляк А. А. Чирлідинг : Правила змагань. Харків, 2005, 82 с.

4. Гавердовский Ю. К. Теория и методика спортивной гимнастики : учебник в 2-х т. Москва: Советский спорт, 2014. Т. 1. 368 с.

5. Долбишева Н. Г., Кидонь В. Закономірності взаємозв'язку технічної, фізичної підготовленості та функціонального стану спортсменок, які займаються естетичною гімнастикою. Фізична культура, спорт та здоров'я нащії: збір. наук. праць. Житомир : Видавець О.О. Євенок, 2017. Вип. 4 (23). C. 30-36.

6. Долбишева Н. Г., Михайліченко А. Г. Технічна та фізична підготовленість черлідирів-флаерів на етапі попередньої базової підготовки. Спортивний вісник Придніпров’я. Дніпро, 2018 № 2. С. 22-26.

7. Зинченко И. А., Луценко Л. С., Бодренкова И. А. Особенности построения тренировочного процесса спортсменов в черлидинге на этапе специализированной базовой подготовки. Слобожанський науково-спортивний вісник. Харків, 2009. № 3. 52 с.

8. Зинченко И. А., Луценко Л. С., Боляк А. А. Управление тренировочным процессом на основе моделирования показателей физической подготовленности спортсменов-черлидеров специализированного этапа подготовки. Слобожанський науково-спортивний вісник. Харків, 2010. № 2. C. 52.

9. Особенности содержания композицій соревновательных программ в черлидинге / И. А. Зинченко, Л. С. Луценко, Н. Л. Боляк, А. А. Боляк. Слобожанський науково-спортивний вісник. 2012. № 3. $74-78 \mathrm{c}$

10. Крекотіна Т. М., Безрядіна Н. Л. Черлидинг. URL : http://zpo.ucoz.ua/Programu_/Fizkylt_sport/ cherlideng.pdf

11. Курамшин Ю. Ф. Теория и методика физической культуры. Москва : Советский спорт, 2010. $320 \mathrm{c}$.

12. Луценко Л. С. Тестовые задания по специально-двигательной и физической подготовленности спортсменов в черлидинге на этапе специализированной базовой подготовки. Физическое воспитание студентов творческих спещииальностей. Харьков, 2009. № 4. С. 45. 
13. Михайліенко А. Г. Технічна підготовка в навчально-тренувальному процесі юних спортсменівчерлідирів на етапі попередньої базової підготовки. Спортивний вісник Придніпров'я. Дніпро, 2018. № 1. C. 55-58.

14. Михайліенко А. Г. Методика вдосконалення технічної підготовки черлідирів на етапі попередньої базової підготовки. Науковий часопис начіонального педагогічного університету ім. М. П. Драгоманова. Науково-педагогічні проблеми фізичної культури. Фізична культура $i$ cnорт: зб. наук. праць / за ред. Г.А. Аорзютова. Київ : Вид-во НПУ ім. М.П. Драгоманова, 2018.

15. Носкова С. А. Черлидинг как инновационный вид спорта в преподавании физической культуры в высшей школе. Теория и практика физической культуры. Харьков, 2002. №6. С. 49-51.

16. Платонов В.Н. Периодизация спортивной подготовки. Общая теория и ее практические приложсения. Киев : Олимпийская литература, 2014. С. 218-229.

17. Платонов В. Н. Система подготовки спортсменов в олимпийском спорте. Общая теория и ее практические приложения. Киев : Олимпийская литература, 2015. 808 с.

18. Самохина Е. А., Седих Н. В. Особенности организации занятий по черлидингу на этапе подготовки к соревнованиям детей 8-11 лет. Физическая культура и спорт. Харьков, 2017. С. 302-315.

19. Худолій О. М. Основи методики викладання гімнастики : навчальний посібник. Харків, 2008. Т. 1. $408 \mathrm{c}$.

20. Чеппел Р. Успешное тренерство по черлидингу. Нью-Йорк : Хьюмон Кинетикс, 1999. 364 с.

21. Human Kinetics. Coaching Y outh Cheerleading (Coaching Y outh Sports Series). Pom H eadridge. 2009. 152 p.

\section{Ref erences:}

[1] Aftaikin, V.S. (2015). Prymenenye uslozhnënnыkh uprazhnenyi dlia razvytyia koordynatsyonnыkh sposobnostei yunыkh cherlydyrov na nachalnom эtape obuchenyia. U chenыe zapysy unyversyteta ymeny P. F. L eshafta. № 5. S. 24.

[2] Beketova, A . N. (2017). "Cherliding”: M etodicheskie ukazaniya. Harkov, 19 s.

[3] Boliak, A . A . (2005). Chyrlidynh : Pravyla zmahan. K harkiv, $82 \mathrm{s.}$

[4] Gaverdovskij, Y u. K. (2014). Teoriya i metodika sportivnoj gimnastiki : uchebnik v 2-h t. Moskva : Sovetskij sport, T. 1. $368 \mathrm{~s}$.

[5] Dolbysheva, N. H., Kydon, V. (2017). Zakonomirnosti vzaiemozviazku tekhnichnoi, fizychnoi pidhotovlenosti ta funktsionalnoho stanu sportsmenok, yaki zaimaiutsia estetychnoiu himnastykoiu. Fizychna kultura, sport ta zdorovia natsii : zbir. nauk. prats. Zhytomyr : V ydavets 0. 0. Y evenok, Vyp. 4 (23). S. 30-36.

[6] Dolbysheva, N. H., M ykhailichenko A. H. (2018). Tekhnichna ta fizychna pidhotovlenist cherlidyrivflaeriv na etapi poperednoi bazovoi pidhotovky. Sportyvnyi visnyk Prydniprovia. Dnipro, № 2. S. 22-26.

[7] Zinchenko, I. A., Lucenko L. S., Bodrenkova I. A . (2009). Osobennosti postroeniya trenirovochnogo processa sportsmenov $v$ cherlidinge na etape specializirovannoj bazovoj podgotovki. Slobozhanskij naukovo-sportivnij visnik. Harkiv, № $3.52 \mathrm{~s}$.

[8] Zinchenko, I. A., Lucenko L. S., Bolyak A . A . (2010). U pravlenie trenirovochnym processom na osnove modelirovaniya pokazatelej fizicheskoj podgotovlennosti sportsmenov-cherliderov specializirovannogo etapa podgotovki. Slobozhanskij naukovo-sportivnij visnik. Harkiv, № 2. S. 52.

[9] Osobennosti soderzhaniya kompozicij sorevnovatelnyh programm $v$ cherlidinge /I. A. Zinchenko, L. S. L ucenko, N. L. B olyak, A. A. B olyak. Slobozhanskij naukovo-sportivnij visnik. 2012. № 3. 74-78 s.

[10] Krekotina, T. M., Bezriadina N.L. Cherlydynh. URL : http://zpo.ucoz.ua/Programu_/Fizkylt_sport/ cherlideng.pdf

[11] K uramshin, Y u. F. (2010). Teoriya i metodika fizicheskoj kultury. M oskva : Sovetskij sport, $320 \mathrm{~s}$.

[12] Lucenko, L.S. (2009). Testovye zadaniya po specialno-dvigatelnoj i fizicheskoj podgotovlennosti sportsmenov $v$ cherlidinge na etape specializirovannoj bazovoj podgotovki. Fizicheskoe vospitanie studentov tvorcheskih special nostej. Harkov, № 4. S. 45.

[13] M ykhailienko, A. H. (2018). Tekhnichna pidhotovka $v$ navchalno-trenuvalnomu protsesi yunykh sportsmeniv-cherlidyriv na etapi poperednoi bazovoi pidhotovky. Sportyvnyi visnyk Prydniprovia. Dnipro, № 1. S. 55-58.

[14] M ykhailienko, A. H. (2018). M etodyka vdoskonalennia tekhnichnoi pidhotovky cherlidyriv na etapi poperednoi bazovoi pidhotovky. Naukovyi chasopys natsional noho pedahohichnoho universytetu im. M.P. Drahomanova. Naukovo-pedahohichni problemy fizychnoi kultury. Fizychna kultura i sport: zb. nauk. prats / za red. H.A. A orziutova. K yiv : V yd-vo NPU im. M .P. Drahomanova. 
[15] Noskova, S. A. (2002). Cherliding kak innovacionnyj vid sporta v prepodavanii fizicheskoj kultury v vysshej shkole. Teoriya i praktika fizicheskoj kultury. Harkov, № 6. S. 49-51.

[16] Platonov, V. N. (2014) Periodizaciya sportivnoj podgotovki. Obshaya teoriya i ee prakticheskie prilozheniya. K iev : Olimpijskaya literatura, S. 218-229.

[17] Platonov, V. N. (2015). Sistema podgotovki sportsmenov v olimpijskom sporte. Obshaya teoriya i ee prakticheskie prilozheniya. Kiev : Olimpijskaya literatura, $808 \mathrm{~s}$.

[18] Samohina, E. A., Sedih N.V. (2017) Osobennosti organizacii zanyatij po cherlidingu na etape podgotovki k sorevnovaniyam detej 8-11 let. Fizicheskaya kul tura i sport. Harkov, C. 302-315.

[19] Khudolii, O. M. (2008). Osnovy metodyky vykladannia himnastyky : navchalnyi posibnyk. Kharkiv, T. $1.408 \mathrm{~s}$.

[20] Cheppel, R. (1999). U speshnoe trenerstvo po cherlidingu. N yu-J ork : Hyumon K inetiks, 364 s.

[21] Human Kinetics. (2009). Coaching Y outh Cheerleading (Coaching Y outh Sports Series). Pom Headridge, 152 p.

\section{ДоЛБЫШЕВА Н.Г., МИХАЙЛИЧЕНКО А. Г. Методика совершенствования технической подготовки чер лидеров на этапе предыдущей базовой подготовки.}

В статье представлена экспериментальная методика совершенствования технической подготовки черлидеров, которая была внедрена в учебно-тренировочный прочесс детей 9-12 лет на этапе предварительной базовой подготовки. Данная методика построена на основе теоретических положений: теории и методики спортивной тренировки, системы подготовки спортсменов в технико-эстетических видах спорта, основных закономерностей проиесса обучения и совершенствования техники физических упражнений в сложнокоординаџионных видах спорта, особенностей подготовки и соревновательной деятельности в черлидинге, особенностей выполнения черлидерами различных функиий в процессе соревновательной композищии. А также предыдущих исследований о месте и значении технической подготовки в учебно-тренировочном процессе юных спортсменов-черлидеров на этапе предварительной базовой подготовки и исходного уровня технической и физической подготовленности спортсменок-черлидеров.

Экспериментальная методика охватывает три уровня технической подготовки, для которых отдельно определены иели и задачи подготовки, собственные средства и методы спортивной тренировки и планировались в соответствии со структурой двухиикловой подготовки с учетом поставленных задач мезоцикла.

Спортивная подготовка по черлидингу построена как круглогодичный прочесс, имеющий определенные временные промежутки для решения основных задач учебно-тренировочного проиесса. Приоритетной стороной черлидиров является техническая подготовка, поскольку основным критерием оценки выступления команды на соревнованиях является качество и сложность выполнения технических элементов. Обоснована методика совершенствования технической подготовки черлидиров 9-12 лет на этапе предварительной базовой подготовки. Установлено, что годовой циикл подготовки юных черлидиров на этапе предварительной базовой подготовки имеет двухцикловую макроструктуру. Воспитывая навыки максимального проявления сил и реализаџии двигательного потенцииала во время выполнения общей композиции, достижения стабильности и вариативности соревновательной композиции, составляющей основу общей деятельности, спортсмены-черлидеры выходят на новый уровень подготовленности.

Ключевые слова: черлидин, черлидеры-база, черлидеры-флаеры, техническая подготовка, техническая подготовленность, этап предварительной базовой подготовки, совершенствования, методика.

Dolbisheva N. G., Mihaylichenko A. G. Methodology of perfection of technical preparation of cheerleaders on the stage of previous base preparation.

$\mathrm{His}$ article presents an experimental methodology for improving technical training for cheerleaders, which was introduced into the training process for children 9-12 years of age at the stage of preliminary basic training. This technique is based on theoretical assumptions: Theories and 
techniques of sports training, the system of training athletes in technical and aesthetic sports, the basic laws of the learning process and the improvement of physical exercise techniques in difficult coordination sports, training and competitive features in cheerleading, features of the cheerleading performance of various functions in the competitive process, and previous studies on the place and importance of technical training in the training process of young chelle athletes Irova in step preliminary base preparation and baseline technical and physical fitness of athletes-cherlidirov.

The experimental methodology covers three levels of technical training for which the goals and objectives of training are separately defined, the own means and methods of sports training and were planned in accordance with the structure of two-cycle summer training taking into account the assigned tasks of the mesocycle.

Cheerleading sports training is built as a year-round process that has certain time intervals for solving the main tasks of the educational process. The priority of the cheerleaders is technical training, since the main criterion for evaluating the performance of a team in competitions is the quality and complexity of the technical elements. The methodology for improving the technical training of cheerleaders of 9-12 years at the stage of preliminary basic training is substantiated. It was established that the annual cycle of training young cheerleaders at the stage of preliminary basic training has a two-cycle macrostructure. Bringing up skills of maximum manifestation of forces and the realization of motor potential during the performance of the overall composition, achievement of stability and variability of the competitive composition, which forms the basis of general activity, cheerleader athletes go to a new level of preparedness.

Keywords: cheerleading, cheerleading base, cheerleading flyers, technical training, technical readiness, the stage of preliminary basic training, improvement, technique.

DOI: https://doi.org/10.31392/NZ-npu-142.2019.10

УДК 378[37.018+78]

Економова О. С., Гаркуша Л. І.

\section{ЕСТЕТИЧНЕ СПРИЙНЯТТЯ ФОРТЕПІАННИХ ТВОРІВ У ПІДГОТОВЦІ СТУДЕНТІВ ДО ПРАКТИЧНОЇ ДІЯЛЬНОСТІ}

В умовах оновлення парадигми мистеиької освіти особлива увага приділяється професійній підготовиі майбутнього вчителя, розвитку виконавської майстерності. Стаття присвячена обтрунтуванню прочесу розвитку творчої особистості в умовах творчоестетичного напрямку профільного навчання. Представлено зміст навчання учнів, що проявляється у педагога мистецьких дисциплін як особистості і як суб’єкта діяльності, в процесі здійснення профільної освіти. В статті розкриваються сутність та характерні риси підходу до проблеми підбору музичного репертуару, щүо має велике значення в педагогізачії навчального прочесу як вагомого чинника формування творчої особистості майбутнього вчителя музики. У статті визначена взасмозалежність особистостей процесу фахової підготовки майбутніх вчителів музичного мистецтвва та наявності в них умінь професійної самореалізації та підбору репертуару, який спрямований на розвиток піаністичних здібностей, формування художнього смаку та художніх иүінностей, в основі яких лежать такі принципи як художня цінність, естетична значущість художніх творів, доступність до виконання, педагогічна доиільність, тематичне, жанрове та стильове різнобарв'я. Серед завдань формування творчого потенціалу студентів є формування художньо-естетичних поглядів, професійної майстерності студентів, досконало підібраний музичний матеріал, який 